\title{
Attribute Perception Mapping Services Domestic Airlines Using Correspondence Analysis
}

\author{
Reni Heviandri Riandarini, Ujang Sumarwan, Kirbrandoko, Lilik Noor \\ Bogor Agricultural University, Bogor
}

\begin{tabular}{l|l}
\hline ARTICLE INFO & ABSTRACT \\
\hline Keywords: & Positioning analysis provides a better understanding of the position
\end{tabular}

Positioning,

Correspondence Analysis,

Full Service Airline (FSA),

Low Fare Airline (LFA) based on the perception of passenger flights to service these attributes attached to each airline. This study aims to perform positioning of the domestic airline services based attributes, which characterize the airline based on the perception of consumers. Correspondence Analysis (CA) is used to determine the positioning of the six commercial airlines in Indonesia. The results of correspondence analysis showed that the airline Garuda, Lion Air, Citilink and Air Asia already has its own characteristics inherent in the minds of consumers, while the two other airlines, namely Batik Air and Sriwijaya Air has not had a special identifier.

(C) 2015 IRJBS, All rights reserved.

\section{INTRODUCTION}

Open-sky policy implementation at the ASEAN (Association of South-East Asian Nations) level in the near future in 2015 requires that Indonesian airlines prepare themselves to reform and innovation so as to face the competition, good competition among domestic airlines as well as the face of competition with other ASEAN airline.

Positioning analysis can be used to identify the strengths and weaknesses of each major airline service so as to explain how the services of a cost compared to its competitors (Wen and
Chen 2010). Research on positioning the airline has been done by several researchers, among others: Kaynak et al. (1994), Gursoy et al. (2008), Surrovitskikh and Lubbe (2008), Wen et al. (2008), Wen and Yeh (2010), Campbell and Ellis (2012), Wang et al. (2014), but according to Gursoy et al. (2005) positioning flights by using the attributes of quality of service has not been carried out, including in Indonesia.

When all airlines offer similar products that will lead to the perception that almost uniformly against all cost, making it difficult for passengers to 
remember the airline through a special identifier that can distinguish between one airline to another airline. Airlines should be able to differentiate themselves in the eyes of consumers by focusing on the quality of service attributes because of their long-term success depends on how well they are positioned in the market (Gursoy, Chen \& Kim 2005).

Al Ries and Jack Trout (1986) stated that the positioning is not what you do to a products, it's what you do in the minds of customers. Way that can be done by marketers to get into the minds of consumers is to be the first then the consumer can remember the brand had in mind. Positioning is an attempt by the company to embed the product image in the minds of their consumers it should be considered that with the increasing number of product benefits offered by it will cause a risk of confusion in the minds of consumers.

According to Kasali (2007) Human interpret a product / brand through perception is associative relationships are saved through the process of sensation, so that perception plays an important role in positioning. Sumarwan (2011) says that the key to positioning is owned by the consumer perception of a product / service companies who want to be seen by the consumer. Every interaction between the passenger and the airline strongly influence their perception of the airline and the airline position in their minds, therefore attribute flight service is a vital component to the success of positioning strategy, so there is a very good understanding of consumers regarding the quality of airline services flight (Gursoy et al. 2005).

In accordance with the above problems, this study aims to analyze the positioning of six domestic airlines in Indonesia based on passenger perception of the service attributes. Through positioning, can identify the cost of consumer perception, identification of market opportunities, knowing the strengths and weaknesses of the company compared to its competitors, the end result can be used to determine or repositioning when needed and to strengthen and improve the positioning in the target market or consumer.

\section{Flight Business Model}

Service competition between full service with low cost service provider gained attention in recent years because the proliferation and popularity of low cost airlines in the world (O'Connell and Williams 2005; Fourier and Lubbe 2006). Manurutng (2010) states that there are three models of aviation business in Indonesia, namely models Full Service Airline (FSA) or that we are familiar with the traditional cost, service models Low Fare Airlines (LFA), and the mixture between the two service models (full service airlines and low fare airlines).

Low Fare Airlines or low-cost airline is airlines that generally offer lower rates by eliminating some of the services that are owned by traditional airlines or full service airlines. The term in the aviation industry is actually referring to the airlines, which has a structure of lower operating costs than their competitors, but the term is often applied also to all airlines with lower ticket prices and limited services, regardless of their operating models (Miller, Vandome and McBrewster 2009). Low fare airline in Indonesia, among other airlines Lion Air, Air Asia, Citilink, Sriwijaya Air, and Mandala (which had ceased operations since the first half of 2014).

According to Manurung (2010) concept full service known as airline business model of traditional (legacy carriers), in this concept, the emphasis is complete and high quality services also at a premium price. Services provided are comprehensive, flexible flight frequency, the grant of lounge facilities, provision of food and drink, a loose seat, entertainment facilities and so forth. Until the year 2012, in Indonesia, Garuda Indonesia, which only uses the concept of full service, but since the year 2013 appeared another airline namely Batik Air that brought the concept of full service airlines. 
The main difference between the Low Fare with traditional airline companies are rate charged, difference rate occurs because the company Low Fare able to cut unnecessary costs and cut services which are not directly related to the operation and in principle can be accepted by customers, the cost differences include sales and reservation, service in the plane, pilot salaries, aircraft ownership, maintenance and ground handling (Hansson et al. 2003).

\section{Quality of Service and Positioning}

Airline service quality is difficult to measure and is defined as having four characteristics services paradigm called IHIP: Intangibility, Heterogeneity, Inseparability, and perishability (Lovelock and Gummeson 2004). Quality of service has become a major concern in the service industry, especially the aviation industry, because the whole process of airline service that starts from the ticketing, check-in, boarding, baggage handling and other services that greatly affect attitudes and satisfaction towards airline passengers. Cost of service attributes are important determinants that influence the choice of airline passengers (Proussaloglou and Koppelman 1999), passenger assess and evaluate the quality of the airline through a comparison between experiences and their expectations on a number of attributes of the service (Grönroos 2000).

Gursoy et al. (2005), stating the time when all airlines have tariffs and service plan that is almost the same, then the key to the success of the airline is doing positioning that can be distinguished based on the attributes of service quality, in a highly competitive conditions today, positioning is one of the most important elements of marketing management. As one of the three pillars of marketing strategy (i.e., segmentation, targeting and positioning) positioning help companies to build competitive advantage (Kotler and Keller 2011). Positioning is a process attempts to place a product, brand, company, individual, or what goes into their minds are considered as the target consumer (Rhenald 2007). Positioning analysis also helps better understanding of consumer perceptions of the product or brand.

In general, the perception mapping uses two types of approaches: multivariate statistics and factoranalytic mapping option. Multivariate statistics, such as correspondence analysis and multidimensional scaling, is requiring the customer perception and product attributes to generate a map of perception (Myers 1996). Analysis positioning often rely on perceptual mapping techniques to describe the competitive position of the product or service (Hooley et al. 2008).

According to Kotler and Keller (2012), there are several strategies that can be applied to the positioning of the company are:

1. Strengthening the position in the minds of consumers, namely by highlighting the state of the company or product that is positive in the market.

2. Search for and seize new position that has not been occupied, by positioning the product as a new category.

3. Shifts or change the position of competitors, is taking the position of a group of products that fall into the best or most when juxtaposed with competitors' products.

4. Strategy exclusive group is taking a position as a product included in the best or largest group when aligned with competitors' products.

Sourced from various previous studies Wen and Chen (2010) identified 18 attributes of airline service quality is very important to be variable positioning. These attributes are: price, convenience of flight schedules, frequency of flights, the convenience of reservation and ticketing, reservation staff service attitude, on-time performance, the queues at the check-in counter, service attitude at the check-in counter, neat and clean appearance and employees, comfort and flexibility seat service, food and beverage services on board, cleanliness on board, on board entertainment facilities, 
hospitality and kindness of the cabin crew, flight safety, handling customer complaints, web site services, and the image of the airline.

\section{Correspondence analysis}

Correspondence analysis is an analysis tool that serves to see the interdependent relationship or interdependence between variables / data. This analysis can be used as a comparison between the products with other products with proximity attributes.

Correspondence analysis is used to visually view whether or not the dependency between categories and to help see the closeness or link a profile from one category to another (Suharjo and Siswadi 1999). Correspondence analysis is also used in the airline positioning research conducted by Gursoy et al. (2005) and Wen et al (2008).

By incorporating all of the attributes of the service used Minitab software to determine the correspondence attributes of existing services, it will be seen a typology of each attribute to the airline. That would look perceptual map between closeness attributes with the name of the airline, which has been predetermined. The influence of each service attribute is determined by the distance of each attribute of the airline brands, the closer the distance to the airline brand, the more powerful the effect.

In this study, correspondence analysis is used to measure the closeness attributes flight service airline Garuda Indonesia, Batik Air, Lion Air, Sriwijaya Air, Citilink, Air Asia. From calculations carried out with the help of software Minitab 16, note that the attributes of service.

By using the software SPSS to determine the correspondence attributes of existing services, it will show the closeness perceptual map attribute with the name of the airline, which has been predetermined. The influence of each service attribute is determined by the distance of each attribute of the airline brands, the closer the distance to the airline brand, the more powerful the effect.

\section{METHODS}

\section{Research Design}

Since it is impossible to obtain a database of passengers from each airline, then the sampling in this study using a non-probability sampling design, i.e., sampling technique which does not give the same chance or opportunity for each element or member of the population to be selected into the sample (sekaran 2003). Types of non-probability sampling are purposive sampling, the method of gathering information from members of the population who meet certain defined criteria (Sekaran 2003). Purposive sampling technique selected in accordance with the scope and limitations of the research requires that the respondent is a domestic flight passengers who have used the two different domestic airlines if the airline Full Service Airline or Low Fare Airline. The technique of non-probability sampling possess a weakness because it can not count the nature and degree of estimation bias (Aaker, Kumay and Day 1998), so that the results can not be generalized to the general population in Indonesia flight.

\section{Variables Research}

To answer this research question, researchers use 22 (twenty two) service attributes according to researchers is essential to measure the airline in Indonesia, is the development of some previous studies on airline service quality attributes that have made Wen and Chen (2010), namely: $\mathrm{X} 1$ (ease of reservation), X2 (ease of ticketing process), X3 (These fairly broad flight), X4 (checkin process speed, X5 (reasonable prices), X6 (punctuality of departure and arrival), X7 (note airline security is quite good), X8 (the airline's reputation is quite good), X9 (flight to quality food), X10 (quality of service during the flight), X11 (quality of service after the flight), X12 (hospitality crew cabin), X13 (cabin crew always helps), X14 (clean cabin space), X15 (cabin crew uniforms 
quite polite), X16 (comfortable chairs), X17 (airline plume), X18 (comfortable cabin space), x19 (airline reliable), X20 (flight which makes passengers feel privileged), X21 (modern aircraft), X22 (professional handle complaints).

\section{Data Analysis Methods}

In this research, the method of analysis used includes DescriptiveStatistics, and Correspondence Analysis (CA). Descriptive analysis aims to get an overview of the characteristics of the respondents, and Correspondence Analysis to analyze the positioning of the airline.

\section{RESULTS AND DISCUSSION}

Profile of Respondents

Positioning All Airlines

Perception or the relationship between psychological stimulus shown as geographic relationship between points in a multidimensional space, the axis of the spatial map showing the psychological basis (psychological base) or underlying dimensions (underlying dimensions) are used by the customer / respondent to shape perceptions and preference for stimulus. Map in Figure 1 looks distribution of airline and vector attributes, the closer the distance between airlines with a vector of attributes, the higher the connection between them.

From Figure 1 can be explained positioning the airline based on the perception of the respondents as follows, airline Full Service Airlines (FSA) in the study is Garuda Indonesia and Batik Air; the airline's second characteristic is positioned with different attributes by respondents.

1. Respondents characterize Garuda Indonesia as airline professional with a good reputation and pride for its customers.

2. When Garuda already has its own positioning in the minds of customers, different thing with Batik Air, a subsidiary of Lion Air, which tries premium market share, as a relatively new addition to the limited service flights are serviced by Air Batik, so do not have a special identifier minds the customer. This Batik Air still clustered with Low Fare Airlines airline other. It was alleged that the respondent still can not distinguish the airline Batik Air as premium class airline Lion Air, as the two airlines are in the management and set off through the same terminal so that the respondent or the passenger is still difficult to distinguish. It takes time and branding strategy for Batik Air in order to really occupy a premium position as desired class and have different attributes that characterized the minds of consumers than the airline class.

3. These-Low Fare other airlines such as Air Asia, Srivijaya and Citilink Lion Air has three distinctive service identifier attributes that flight service, check-in process speed and affordable prices.

\section{Low Fare Airline (LFA) Airlines Positioning}

To view the positioning of the operators Low Fare Airline, then at a later stage positioning attributes and services by issuing Garuda Batik Air as a Full Service Airline operators (FSA), as Figure 2 below, the map perception among airline flight service attributes Low Fare Airlines, which indicates:

1. Respondents position Lion Air separately as the airline with an attribute that has a flight path (route) carrier large enough and affordable prices. Strategies its aircraft fleet with Boeing aircraft using the latest series, namely 737-900 ER (Extended Range) with a longer body size also gives a special meaning in the minds of consumers. Lion Air's business growth over the past six years is quite significant with the increase of the fleet so that more passengers can be transported. The addition of routes and frequency of flights and the airline makes this as ruler domestic aviation market. Complaints from some customers that they are often aimed at the airlines is about aviation safety, low cost and lack of timeliness and less friendly cabin crew service.

2. The results show that Sriwijaya Air has a close distance with the Citilink. The proximity 


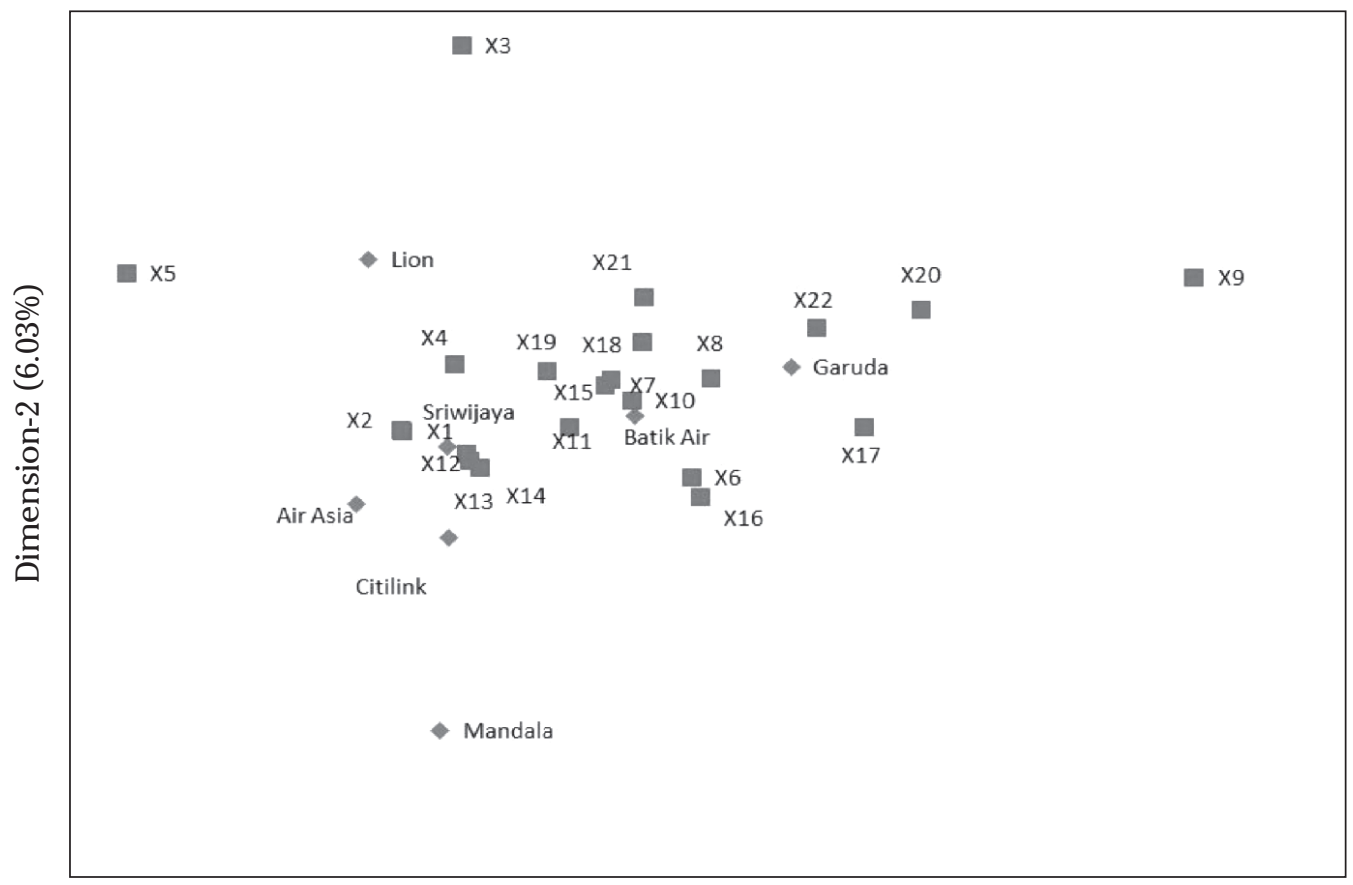

Dimension-1 (90.28\%)

Figure 1. Map of the perception of the entire airline service attributes (FSA and LFA)

\section{Specification:}

X1Ease of reservation.

$\mathrm{X} 2$ Ease ticketing process.

X3 Flight route

$\mathrm{X} 4$ Check-in process speed

X5 Affordable prices

$\mathrm{X} 6$ Timeliness

X7 Flight safety record

X8 Good reputation pretty airline

X9 Quality food

$\mathrm{X} 10$ Good service quality in the cabin

X11 Good post-flight service
X12 Quite friendly cabin crew X13 Cabin crew always helps X14 Aircraft cabin is clean enough $\mathrm{X} 15$ Cabin crew uniform is quite polite X16 Aircraft seats quite comfortable $\mathrm{X} 17$ Proud flew with this plane X18 Quite comfortable cabin space X19 Reliable airline X20 Feel privileged when flying X21 modern aircraft X22 Professional shows that the airline is competing with the service attributes in almost the same position by the consumer. When Citilink, positioned by the respondent through attributes departure timeliness of, comfortable seats with legroom in economy class, and this is the plane that gives a sense of pride for customers who use the airline. While the Srivijaya not have a special identifier flight services because of the close spacing of Sriwijaya Air with various attributes flight services.
3. Air Asia is characterized by respondents to the service of his pre-journey through the ease of reservation and ticketing process.

\section{MANAGERIAL IMPLICATIONS}

Airline customers are more likely to remember an airline based on one or more unique attributes the airline possesses, as stated by Jones et al. (2002) in which airline customers tend to be loyal to an airline because of the service characteristics. In fact, customers who are not satisfied with the 


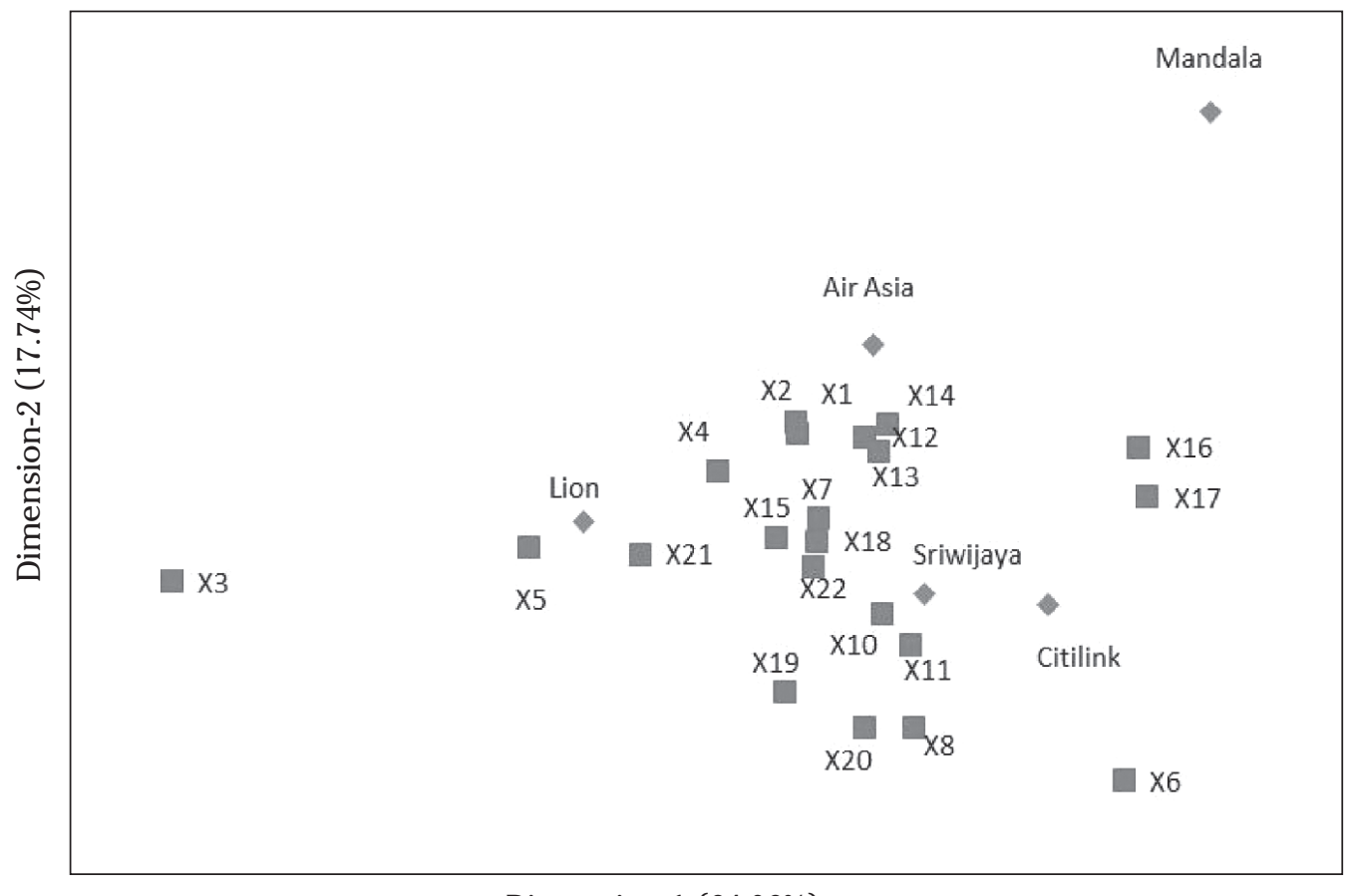

Dimension-1 (64.06\%)

Figure 2. Map of the perception of the attributes of airline service LFA

\section{Specification:}

$\mathrm{X} 1$ Ease of reservation.

$\mathrm{X} 2$ Ease ticketing process.

X3 Flight route

X4 Check-in process speed

X5 Affordable prices

$\mathrm{X} 6$ Timeliness

X7 Flight safety record

X8 Good reputation pretty airline

X9 Quality food

$\mathrm{X} 10$ Good service quality in the cabin

X11 Good post-flight service
X12 Quite friendly cabin crew

X13 Cabin crew always helps

X14 Aircraft cabin is clean enough

$\mathrm{X} 15$ Cabin crew uniform is quite polite

X16 Aircraft seats quite comfortable

X17 Proud flew with this plane

X18 Quite comfortable cabin space

X19 Reliable airline

X20 Feel privileged when flying

$\mathrm{X} 21$ modern aircraft

X22 Professional service quality can continually using a certain airline instead of switching to a different airline. Almost every airlines that were used as samples for this research already have special characteristics the customers remembered. Garuda Indonesia was positioned by customers as an airline with good reputation, good quality food, and they feel proud to fly with. A good reputation and ability to make customers feel proud are service attributes which are difficult for other airlines to copy. Those advantages are used by Garuda airline to stay being the chosen FSA airline in the country. Garuda Indonesia's continuous efforts to maintain its reputation, increasing service quality and knitting a close relationship with their customers will make it hard for other FSA airlines to compete with it.

Batik Air, another FSA airline, doesn't have any characterizing attribute that's memorable for customers yet. There are still a lot of airline service users who still don't recognize Batik Air. Because 
of it, the management of Batik Air have to work hard to increase the airline brand awareness so that general public more aware of it. The management of Batik Air must increase their airline promotion, either by electronic media, print media or any other kind of media, as to be recognize by general public. Batik Air promotion must include characterization that is different than any other FSA airlines so that it will have a unique character that is to remember by people who use airline service.

Most LFA airlines already have special characteristics that are easy to remember by consumers. Lion Air was positioned by customers as airline with great variety of flight routes, inexpensive ticket price, and modern planes. Citilink with punctuality and comfortable seats. Air Asia was positioned as airline with easy reservation and ticketing, while Sriwijaya Air was the only LFA airline with no special characteristic that the customers can remember.

Findings from this study must significantly help airlines to identify their closest competitor, their strengths and weaknesses, and also identifying competitive advantage from service quality that the customers felt so that they can improve as to position themselves in national commercial aviation. Facing ASEAN open sky, each airlines must be able to develop and expand their flight network in other ASEAN territory, by maintaining the special characteristics of service that are easy to remember and interesting for consumers or by creating special characteristics for other services that can attract more consumers.

\section{CONCLUSION}

Correspondence analysis shows that the main identifier FSA airline Garuda Indonesia is the airline with a good reputation, proud while flying with Garuda, feel privileged as a passenger as well as food quality. Lion Air is the main identifier flight path (route) is quite extensive airline, ticket prices affordable, and modern aircraft. Citilink has a fairly favorable positioning associated with big names attached to Garuda Indonesia, to increase market share is a sense of pride when flying by using Citilink. Air Asia is characterized by a pre-journey namely ease of reservation and ticketing, while Sriwijaya Air and Batik Air, yet have a primary identifier that allows consumers to remember and distinguishing characteristic of both airlines with other airlines.

This study can not be used to generalize the positioning of the airline, due to limited decisionresponder that passengers departing domestic flights only through Soekarno-Hatta Airport. Future studies should be done at some airports as well as sampling of respondents both domestic and international flights both short-haul flights and long distance, because of the needs and desires of passengers will be different.

\section{REFERENCES}

AtalikO, EminO. 2007. Passenger Expectations and Factors Affecting Their Choice of Low Cost Carriers-Pegasus Airlines. Paper presented at the Northeast Business and Economics Association conference, Central Connecticut State University, New Britain, November 7-9

Campbell B, Vigar-EllisD. 2012. The Importance of Choice Attributes and The Positions of The Airlines within The South African Domestic Passenger Airline Industry as Perceived by Passengers at Durban International Airport. Southern African Business Review, 16 (2): 97-119.

Evangelho F, Huse CY,Linhares A. 2005. Market Entry of ALow Cost Airline and Impacts on the Brazilian Business Travelers. Journal of Air Transport Management, 11:99-105. 
Fourie CY,Lubbe B. 2006. Determinants of Selection of Full-Service Airlines and Low-Cost Carriers. A Note on Business Travellers in South Africa. Journal of Air Transport Management. 12:98-102.

Gursoy D, Chen M, Kim HJ. 2005. The US Airlines Relative Positioning based on Attributes of Service Quality. Tourism Management, 26(1):57-67.

HanlonP.2007. Global airlines: competition in a transnational industry. $3^{\text {rd }}$ ed. Burlington, MA: Butterworth-Heinemann

Kasali R. 2007. Manajemen Periklanan: Konsep dan Aplikasinya di Indonesia. Jakarta: Pustaka Utama Grafiti

Kaynak E, Kucukemiroglu O, Kara A. 1994. Consumer's Perceptions of Airlines: A Correspondence Analysis Approach in a Global Airline Industry. Management International Review, 34: 235-254.

Lovelock C, Gummersson E. 2004. Whither Service Marketing?. In Search of a New Paradigm and Fresh Perspectives. Journal of Service Rersearch,7(1):20-41

Mason K. 2001. Marketing Low Cost Airline Services to Business Travelers. Journal of Air Transportation Management, 7(2):103109

Mason KJ, Alamdari F. 2007. EU Network Carriers, Low Cost Carriers and Consumer Behaviour: a Delphi study of Future Trends. Journal of Air Transport Management,13: 299-310.

Manurung L. 2010. Strategi dan Inovasi Model Bisnis Meningkatkan Kinerja Usaha: Studi Empiris Industri Penerbangan Indonesia. Jakarta: Elex Media Komputindo.

O'connell JF, Williams G. 2005. Passengers' perceptions of low cost airlines and full service carriers: A case study involving Ryanair, Aer Lingus, Air Asia and Malaysia Airlines. Journal of Air Transport Management, 11:259-272.

Ries Al, Jack Trout. 1986. Positioning: The Battle for Your Mind. New York: Mcgraw-Hill Book Company.

Shaw S. 2007. Airline Marketing and Management. Sixth Edition. Ashgate Publicing Limited. England

Siomkos, George J. 2000. Managing Airline Disasters-The Role of Consumer Safety Perceptions and Sense-Making. Journal of Air Transport Management,6(2): 101-108.

Suharjo B, Siswadi. 1999. Analisis Data Peubah Ganda dan SPSS 7.5. Bogor : FMIPA IPB.

Sumarwan U. 2011. Perilaku Konsumen. Teori dan Penerapannya dalam Pemasaran. Edisi Kedua. Jakarta: Ghalia Indonesia.

Surovitskikh, S. and B. Lubbe. 2008. Positioning of Selected Middle Eastern Airline in the South African Business and Leisure Travel Environment. Journal of Air Transport Management 14, pp. 75-81.

Wang, J., Wu, J., Wang, L., \& Li, M. (2014). Empirical study of airline service dimensions in China. Journal of Economics, Business and Management, 2(1), 17-21.

Wen CH, Lai SC, Yeh WY. 2008. Segmentation and Positioning Analysis for International Air Travel Market: The Case of TaipeiTokyo Route. Transportation Research Record 2052:46-53.

Wen CH. Yeh WY. 2010. Positioning of International Air Passenger Carriers using Multidimensional Scaling and Correspondence Analysis. Transportation Journal, 49:7-23.

Wen CH, ChenWY. 2011. Using Multiple Correspondence Cluster Analysis to Map the Competitive Position of Airlines. Journal of Air Transport Management 17 (5):302-304

Wen CH, Chen TN, Fu C. 2014.A Factor Analytic Generalized Nested Logit Model for Determining Market Position of Airlines. Departement of Transportation Technology and Management, Feng Chia University, 100.Wenhwa Road, Seatwen, Taichung. Taiwan. Transportation Research Part A 62:71-80. 